AREA Forum

\title{
HOW TO COMMUNICATE COMPLEX SCIENTIFIC CONCEPTS TO ARBORISTS AND EDUCATORS
}

The Arboricultural Research and Education Academy (AREA) is starting a series of dialogues dealing with a variety of issues in arboriculture. Our first discussion topic is "How to communicate complex scientific concepts to arborists and educators." We have asked four of our members to submit their thoughts on the subject. We invite additional commentary to be submitted for inclusion in future issues. You may send your response to the Journal Editor (see inside cover) or to me at ach@ho9000a1.uam.mx.

Alicia Chacalo

President, AREA

\section{Bonnie Lee Appleton Virginia Tech University}

First, determine what the one or two major concepts are that you wish to convey or on which you want to concentrate. Leave out items that might be of interest on a basic level to a scientist, but which are of no real consequence to a practitioner on an applied level. (If the concept is in written form, take a red pen to it and start crossing out the "nice, but extra" items.) Second, look for simpler or more common words to substitute for those that might not be easily or readily understood. If an analogy can be developed using examples of items better understood by your intended audience, develop one. If an illustration or picture would better explain the concept, do "show" but not "tell." Try the reworded, analogous, or illustrated version on someone without a scientific background. Each time a puzzled look or a question occurs, decide whether the confusing item is important enough to keep. If it is, "revise downward"; if not, drop it.

\section{Susan Wiegrefe The Morton Arboretum}

In my experience, it is most effective to respectfully assume the very worst about how much your audience knows about your field of investigation and related scientific concepts. They may have absorbed just as much of the tide of information assaulting all of us since before kindergarten, but in all likelihood, it is a much different subset than what you have absorbed. To bridge the gap:

1. Start with the basics by reviewing supporting concepts your audience will need to know. Especially when addressing more than one individual, make sure they understand you from the start. It will be much less frustrating for both you and your audience than trying to identify missing planks and make repairs threequarters of the way through your explanation.

2. Be very careful not to use jargon. It may make you appear concise and informed among your scientific peers, but it will further ingrain in others the widely held opinion that academics don't speak plain English (or Spanish or Swedish) and strive only to impress or intimidate others with their knowledge of obscure words.

3. Employ imagery to help the audience visualize concepts. Even if it's in their imagination, a picture is still more effective than many hundreds of words. An example would be to liken genes to beads on a string.

4. Use examples that you know the audience can relate to and that acknowledge their expertise. Draw them in by using examples of things they know and care about. To illustrate the concept 
of convergent evolution, you could draw on the familiar Norway and sugar maples (Acer saccharum and $A$. platanoides) as examples of trees that look similar but have different evolutionary histories. Silver and red maple (A. saccharinum and $A$. rubrum) illustrate the concept of trees with a similar or joined evolutionary history that are generally easy to distinguish.

5. When giving a presentation, be alert for nonverbal signs that you've lost your audience. Symptoms of this include: they no longer are making eye contact, they have begun crossing their arms or stroking their chin, they stand or sit with their body turned away at a greater angle than before. Some of these sign can also indicate disbelief or disagreement. Stop and ask if they still understand your line of explanation before deciding how to best continue (see \#1).

6. Be as brief as possible. Very few people will have a desire to know as much about a topic as you are capable of delivering to them. Minimize theory and methodology.

7. Appeal to your audience's self interest. Focus on the implications the research has for your listeners and the rest of society. Knowing that it is somehow important to them will help them listen long enough to understand the concepts involved.

Explaining complex issues to arborists or educators is not that different from explaining your line of work to a cherished, nonscientific family member or acquaintance. For effective communication, one of the best pieces of advice is still to follow the KISS principle: Keep It Short and Simple.

\section{Roger Kjelgren \\ Utah State University}

Scientific research is the fuel that drives the technological engine that, for better or for worse, has created today's western society. This inverted food chain, where information emanates from the few to the many, benefits arboriculture through more efficient tools and clearer understanding of tree growth and development. Historically, this has been a pro- cess diffusive and slow. However, the care and management of trees is facing external demands for more environmentally sensitive and economically aware decision-making predicated on sound scientific knowledge. Arborists and educators need information about low-impact pest management, more efficient water and nutrient resource usage, and ecologically aware tree species selection to make, or to train others to make, these decisions. The flow of scientific information to the arborist and educator can be better assimilated and made more accessible by careful use of images and the World Wide Web. People make information their by own creating mental images of the information that they can easily access, and the easiest way to develop that imagery of complex scientific concepts is through creative visuals and computers. A source of scientific information combined with creative visualization on computer can be made readily available to the target audience by posting on the Web. The key then to communicating complex scientific concepts to the arboricultural community is for researchers to partner with communicators who can bring research results to life with creative and interactive visuals.

\section{Sharon Lilly International Society of Arboriculture}

There seems to be an ever-present communication gap between researchers and practitioners. Although the problem isn't limited to the field of arboriculture, in this profession the gap can sometimes approach canyon proportions. Researchers publish results of their studies in scientific journals, read mostly by other scientists. Scientists often write in the passive voice, using subject-specific vernacular and peppering their manuscripts with statistical jargon. These papers, as written, are inappropriate for popular trade publications and newsletters.

It is important for authors to know their audience. The writer has the responsibility of communicating his or her message to the reader; failure to convey the information and explain the concepts is the fault of the writer, not the reader. Here are a few tips to remember when preparing an article for nonscientific publications. 
1. Don't speak down to the audience. A condescending tone is insulting and will alienate and distract the reader.

2. Decide exactly which part of the information is relevant. Statistical significance, for example, can be communicated in a summary without presenting the raw data.

3. Write in the active voice. Simple, declarative sentences can be very effective and easy to read.

4. Be direct. Avoid using long sentences and paragraphs that cause the reader to review passages more than once.
5. Use language familiar to the audience. Using technical terms is acceptable if such words are part of the common vocabulary. Do not try to impress the audience by expressing a point in the most complex language imaginable. Research and technical advancements have no value if they are not transferred into practice. Thoughtful communication builds bridges by which information is conveyed from source to sink. 